\title{
Nafoxidine Hydrochloride
}

National Cancer Institute

\section{Source}

National Cancer Institute. Nafoxidine Hydrochloride. NCI Thesaurus. Code C1448.

The hydrochloride salt of the partial estrogen antagonist nafoxidine. Nafoxidine competes with endogenous estrogen for binding to specific estrogen receptors. This agent also inhibits angiogenesis in some tissues by blocking the effects of fibroblast growth factor (FGF) and vascular endothelial growth factor (VEGF); paradoxically, it may enhance angiogenesis in uterine tissue. Nafoxidine also induces oxidative stress, protein kinase $\mathrm{C}$ and calcium signaling. ( $\mathrm{NCIO4)}$ 